\title{
Exploration and Construction of Innovation and Entrepreneurship Education Curriculum System in Civil Engineering Specialty
}

\author{
Ji Min, Jiang Bolin, Chen Shuzhen \\ Chongqing Vocational Institute of Engineering \\ No.1 Nanbei Avenue, Bingjiang new town, Jiangjin district, Chongqing, China 402260
}

\begin{abstract}
Innovation and entrepreneurship education is a systematic project. The key to promoting the development of college students' innovation and entrepreneurship education is to build a reasonable curriculum of innovation and entrepreneurship education. In particular, the curriculum system suitable for professional development is the need for personnel training goal, and it is also the need to improve the core competitiveness of the professional. With current rapid development of the construction industry, a variety of new materials, new technologies, new construction methods emerge in an endless stream, there is urgently need to adapt to economic development and technological innovation of entrepreneurial talents. Therefore, it is an important and urgent task to establish an innovative entrepreneurship education curriculum system for civil engineering majors and to cultivate applied talents with innovative spirit, entrepreneurial awareness, and entrepreneurial ability. This paper builds a teaching system for civil engineering courses based on the cultivation of innovation and entrepreneurship, and strives to explore ways to improve the quality of curriculum teaching. It aims to provide guarantees for the cultivation of college students' innovative and entrepreneurial abilities, and actively promotes the participation of civil engineering students in the industry of innovation and entrepreneurship.
\end{abstract}

Keywords-Civil engineering; Innovation and entrepreneurship; Education system; Innovation and Entrepreneurship

\section{INTRODUCTION}

The "Implementation Opinions on Deepening the Reform of Innovation and Entrepreneurship Education in Higher Education Institutions" published by the General Office of the State Council requires that the reform of innovation and entrepreneurship education in colleges and universities be fully deepened in 2015 [1]. The "Opinions" stress that deepening the reform of innovation and entrepreneurship education in colleges and universities as a breakthrough in promoting comprehensive reform of higher education. For a long time, innovation and entrepreneurship education in local colleges

Project support: Chongqing Municipal Education Commission Higher Education Teaching Reform Research Funding Project (Project No. 183238), Science and Technology Research Program of Chongqing Municipal Education Commission (Grant No.KJQN201803407), Chongqing Vocational Institute of Engineering Education and Teaching Reform Research Project Funding Project (Project No. JG171002). and universities [2] has been tied with the problem of collegestudent recruitment and employment. In fact, innovation and entrepreneurship education is ultimately a major task for applied talents and outstanding engineers, and it provides a solid talent base for popular entrepreneurship and innovation among innovation-driven strategies. Local colleges and universities should fully promote the nine major tasks, while taking full advantage of the favorable timing of current education reform [3], combining the characteristics of regional development, timely improve the integration of innovation and entrepreneurship education and civil engineering, and promote innovation and entrepreneurship education to achieve substantial results. The integration of innovation, entrepreneurship and professionalism is an indispensable link in the implementation of innovation and entrepreneurship education. Therefore, this paper builds a teaching system for civil engineering courses based on the cultivation of innovation and entrepreneurship, and strives to explore ways to improve the quality of curriculum teaching. It is expected that college students majoring in civil engineering will be encouraged to invest in innovation and entrepreneurship [5].

\section{THE CONNOTATION OF INNOVATION AND ENTREPRENEURSHIP EDUCATION}

Since the grand strategy of "Mass entrepreneurship and innovation" has been proposed, its purpose is to promote and maintain sound economic development under the new normal [4]. On the one hand, only through innovation, can we create more new technologies, new products and new benefits; On the other hand, only through mass entrepreneurship and the addition of more market players can the market's motivation and competitiveness be enhanced and new vitality stimulated. The primary function of colleges and universities is talent cultivation [6], which is the main channel for cultivating innovative and entrepreneurial talents. Innovating entrepreneurship education must not only improve innovation and entrepreneurship, but also foster entrepreneurial awareness and innovation spirit, especially the expansion of innovative practice operational capabilities. To make innovation and entrepreneurship education smoothly implemented in colleges and universities, it is necessary to use practical teaching to train talents who have the ability to use 
innovative thinking, have pioneering [7], adventurous and practical abilities, and have entrepreneurial ability.

To this end, we must establish a practical teaching system for innovation and entrepreneurship, establish a practice base for innovation and entrepreneurship education, form a quality assurance system for innovation and entrepreneurship education, and identify innovation and entrepreneurship practice teaching methods in order to improve students' ability to independently innovate and start businesses [8]. This is also an applied talent cultivation model. Fundamental change.

\section{THE STATUS QUO OF INNOVATION AND}

\section{ENTREPRENEURSHIP EDUCATION AT HOME AND ABROAD}

The innovation and entrepreneurship education has been highly valued in developed countries, and the development is quite large. Since 1967, Babson Business School has launched the first graduate entrepreneurship program in the world. The United States has formed a relatively scientific and perfect entrepreneurship education teaching and research system. Professors from London Business School in the United Kingdom conducted a survey on the development of entrepreneurship education. At least $55 \%$ of UK universities have established one or more entrepreneurship education courses [9], and there has been a further increase. Japan's innovation and entrepreneurship education focuses on fostering entrepreneurial spirit and entrepreneurial ability. It is a three-dimensional system consisting of universities, university venture companies, entrepreneurship courses, and internships.

China's innovation and entrepreneurship education started relatively late. In April 2002 [10], nine institutions, including Tsinghua University, were identified by the Ministry of Education as the first batch of pilot colleges for entrepreneurship education, and entrepreneurship courses were set up. In 2006, the Ministry of Education piloted the Innovative Experiment Project for Undergraduate Students at some colleges and universities. During the "12th Five-Year Plan" period, the "Innovative Experiment Program for Undergraduates" was renamed the "Innovation and Entrepreneurship Training Program for Undergraduates," and the program was expanded in terms of form and quantity. On May 4, 2010, the Ministry of Education issued a document entitled "Strengthening the Opinions on Innovation and Entrepreneurial Education in Colleges and Universities and the Self-starting Work for College Students," marking the start-up of innovation and entrepreneurship education and its promotion throughout the country. In 2015, Premier Li Keqiang once again proposed innovation and entrepreneurship education [11], and innovation and entrepreneurship formally culminated in the country.

However, at present, the following major problems exist in the innovation and entrepreneurship education in Chinese colleges and universities [12].

(1)The entrepreneurial theory curriculum is simple and mostly takes the form of elective courses. Teaching materials, teachers, and assessment methods are not perfect. There is no systematic system of innovation and entrepreneurship education.
(2)The practice of innovation and entrepreneurship education is simple, and there are fewer activities that combine with the market.

(3)College students have a serious "thinking tendency" for employment and job selection after graduation, and they do not have the awareness of entrepreneurship, self-employment, and self-employment. The entrepreneurial field of college students is mainly concentrated in the service industry, especially trade, circulation, logistics and so on. Graduates of engineering colleges start their own business

\section{BASIC PRINCIPLES OF CURRICULUM SYSTEM CONSTRUCTION}

The construction of the curriculum system is a systematic project. In conjunction with the current practice of adult education, the following three basic principles can be followed.

\section{A. The organic unity of theory and practice}

Constructing the course system of adult innovation and entrepreneurship education must emphasize the training of theory. Adult education in colleges and universities is often guided by actual needs, with a single focus on cultivating students' practical skills. This requires the advantage of general education in colleges and universities and the training of theoretical abilities in the setting of curriculum system. Although adult students are relatively weak in theoretical understanding as compared with general education students, as long as they are carefully and rationally arranged and arranged, they will certainly be able to create a talent team that complements theory and practice.

\section{B. The effective combination of entrepreneurship education and professional education}

Innovation leads entrepreneurship, entrepreneurship promotes employment. The goal of innovation lies in entrepreneurship. The role of entrepreneurship is to promote economic growth while stimulating greater employment. This requires that when constructing the adult education curriculum system, entrepreneurship education should be integrated into professional education, and innovation and entrepreneurship should be the spirit of each course. This spirit of pioneering, enterprising, and hardworking should be integrated into the student's personality. Through the reform of the teaching system and curriculum setting, the purpose of entrepreneurship education and the comprehensiveness of professional education are emphasized.

\section{The lifelong nature of innovation and entrepreneurship education}

Adult education in colleges and universities should not end with the graduation of the students. Adult education needs to be integrated with lifelong education. This way, the continuation of content and the lifetime of education are integrated into the curriculum construction. The essence of innovation education lies in continuous development. Therefore, the contents of any course cannot be changed and once and for all. At the same time, the development of students is also a continuous dynamic process. With the 
development of the frontiers of disciplines, it needs continuous improvement and supplementation [14].

\section{REFORM MEASURES FOR INNOVATION AND ENTREPRENEURSHIP EDUCATION IN TRAINING CIVIL ENGINEERING PROFESSIONALS}

\section{A. Revise Talent Training Program and Improve the Curriculum System of Innovation and Entrepreneurship Education}

1) Revise the talent training program

According to the newly revised national standards for undergraduate professional teaching quality and the objectives of undergraduate innovation and entrepreneurship education, as well as professional evaluation standards formulated by industry departments, combined with the positioning of our school and service orientation, we will formulate new professional teaching quality standards and revise personnel training programs, and integrate innovation and entrepreneurship education into the entire process of personnel training.

2) Improve the innovation and entrepreneurship education curriculum system

According to the school's personnel training orientation and the goal of innovation and entrepreneurship education, we must scientifically construct a professional curriculum system, optimize curriculum content, standardize curriculum construction quality standards, accelerate the progress of internationalized curriculum construction, and comprehensively improve the level of curriculum construction. In the process of imparting professional knowledge, it explores and enriches innovation and entrepreneurship education resources for various professional courses, and promotes organic integration of professional education and innovation and entrepreneurship education.

\section{B. Deepen educational methods and examination methods,} and use Internet to promote modern education methods

1) Deepen the reform of teaching methods

Heuristic, discussion, and participatory teaching methods were widely carried out, gradually promoting small class teaching, implementing hierarchical teaching, and cultivating students' innovative and entrepreneurial thinking.

\section{2) Deepen reform of examination methods}

The reform of examination methods for professional courses has been promoted in an all-round manner. With the goal of cultivating outstanding engineers in civil engineering, the national registration examination model has been implemented, reforms of examination methods suited to the characteristics of disciplines and specialties and taking into consideration the assessment of the learning process have been carried out, and non-standard answer examinations have been actively explored.
3) Promote the use of modern education methods and the construction of network resources

Teachers must master modern educational technology and methods, and introduce and build a number of online open courses such as micro-curricular, muck, and video open classes in high-quality innovation and entrepreneurship education to provide students with rich and diverse quality education resources for independent learning, innovation and entrepreneurship.

\section{Strengthen the Construction of Teaching Staff for} Innovative and Entrepreneurial Education to Improve the Teaching and Learning Ability of Teachers in Innovation and Entrepreneurship Education

1) Strengthen the building of a faculty for innovation and entrepreneurship education

Gradually build a team of professional teachers, experimental teachers, researchers and full-time entrepreneurial and career guidance teachers, social wellknown entrepreneurs, entrepreneurial successors, experts and scholars, and outstanding alumni as part-time innovation and entrepreneurial mentors. This is a combination of professional and part-time high-quality innovation and entrepreneurship education teachers.

2) Improve teachers' ability of innovation and entrepreneurship education and teaching

We will continue to implement the system of teachers' enterprise practice and the system of teachers' professional comprehensive competency, formulate training systems for teachers' innovation and entrepreneurship education and teaching ability, and enhance the ability of teachers' engineering practice and innovation and entrepreneurship education.

\section{Build a Platform for Innovation and Entrepreneurship, and Strengthen the Practice of Innovation}

1) Strengthen the construction of experimental teaching resources and establish a sharing mechanism

we should vigorously promote the reform of practical teaching, optimize experimental teaching systems, update experimental teaching programs and content, and increase the proportion of academic hours in comprehensive, design, and innovative experiments. Establish experimental teaching platform sharing mechanism and safeguard system. We will improve the relevant regulations for the open management of our laboratories, promote the opening of all types of laboratories for all students, and provide services for students engaging in activities such as innovation and entrepreneurship. Further clarify the functional positioning of engineering training centers, rational planning, and strengthen the construction of engineering training centers, specialized laboratories, entrepreneurial laboratories, and multidisciplinary virtual simulation experimental teaching platforms, making them a base for improving students' engineering capabilities and innovation and entrepreneurship. 
2) Vigorously promote the construction of innovation and entrepreneurship education practice base

In accordance with the principles of integrating resources, standardizing operations, highlighting key points, and advancing step by step, special venues have been allocated, special funds have been invested, and a practical innovation and entrepreneurship education base has been built that integrates innovation and entrepreneurship education training, simulation practice, guidance services, and exchange demonstration. At the same time, it is necessary to strengthen cooperation with local technology development zones, science and technology parks, enterprises, institutions, scientific research institutes, and outstanding alumni companies, and to strengthen the construction of a base for innovation and entrepreneurship education outside the campus.

\section{SUMMARY}

Civil engineering course teaching reform plays an important role in cultivating the ability of innovation and entrepreneurship, and is an important way to realize the grand goal of "mass entrepreneurship and innovation". To make innovation and entrepreneurship education smoothly implemented in the civil engineering major, it is necessary to build a practical teaching system based on the cultivation of innovation and entrepreneurship, and continue to carry out theoretical research, content updates, and institutional guarantees on this system. Only in this way can talents with innovative ability, entrepreneurial ability and scientific thinking ability be cultivated, can they achieve the organic integration of the applied talents training target of civil engineering and social needs.

\section{REFERENCES}

[1] Chen J L, Liang Q. The Research of Training Model of Excellence Engineer in Teaching University of Applied Civil Engineering[J]. China Construction Education, 2010.

[2] Wieser P. L'innovation dans la supply chain: de l'idée à la mise en oeuvre[C]// Colloque INNOVACS. 2010.

[3] Baillie C, Foster D. The socially just engineer and socia entrepreneurship - the case of Waste-for-Life, Argentina[C]// Engineers Australia, 2011.

[4] Pancholi S, Yigitcanlar T, Guaralda M. Urban knowledge and innovation spaces : concepts, conditions, and contexts[J]. Asia Pacific Journal of Innovation \& Entrepreneurship, 2014.

[5] Lu C, Zhu H. Comparative study of innovation and entrepreneurship education $[\mathrm{C}] / /$ International Conference on Computer Science and Education. IEEE, 2017:629-633.

[6] Pancholi S, Yigitcanlar T, Guaralda M. Urban knowledge and innovation spaces : concepts, conditions, and contexts[J]. Asia Pacific Journal of Innovation \& Entrepreneurship, 2014.

[7] Beiler M R O. Integrating Innovation and Entrepreneurship Principles into the Civil Engineering Curriculum[J]. Journal of Professional Issues in Engineering Education \& Practice, 2015, 141(3):04014014.

[8] Fang G, University Y. Research on the evaluation system of innovation and entrepreneurship of civil engineering in local colleges[J]. Shanx Architecture, 2016.

[9] Etzkowitz H. Making a humanities town: knowledge-infused clusters, civic entrepreneurship and civil society in local innovation systems[J] Triple Helix, 2015, 2(1):1.

[10] Fang G, University Y. Research on the evaluation system of innovation and entrepreneurship of civil engineering in local colleges[J]. Shanxi Architecture, 2016.

[11] Xudong F U, Lihua X U, Xinxi D U, et al. Exploration and practice of the plan for educating and training outstanding engineers of civil engineering specialty[J]. Journal of Architectural Education in Institutions of Higher Learning, 2014.

[12] Lu C, Zhu H. Comparative study of innovation and entrepreneurship education[C]// International Conference on Computer Science and Education. IEEE, 2017:629-633.

[13] Kruk M M. Strategy of Research Institutes in Construction in Shaping the Research Area[J]. Archives of Civil Engineering, 2017, 62(4)

[14] Tianqi L I, Zou Y, Wang D, et al. Study and practice of innovative and entrepreneurial talent cultivation in civil engineering specialty[J]. Journal of Architectural Education in Institutions of Higher Learning, 2018 